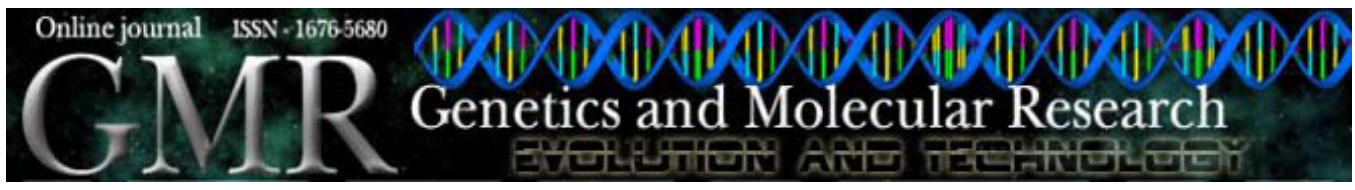

\title{
Salt stress causes a shift in the localization pattern of germin gene expression
}

\author{
M. Caliskan \\ Department of Biology, Mustafa Kemal University, Hatay, Turkey \\ Corresponding author: M. Caliskan \\ E-mail: caliskanm@gmail.com
}

Genet. Mol. Res. 8 (4): 1250-1256 (2009)

Received April 3, 2009

Accepted June 29, 2009

Published October 20, 2009

\begin{abstract}
The response of plants to biotic and abiotic stress factors involves biochemical, physiological, morphological, and developmental changes. Salt stress has been the subject of extensive studies due to the low salt tolerance of many crop plants. Germin and germin-like gene products are known to be involved in various aspects of plant development, such as defense, embryonic development and response to biotic as well as abiotic stress, including salt. The responses of germin and germin-like genes to salt stress vary in different plants. RT-PCR and in situ RNA hybridization methods were employed to analyze quantitative changes and to detect the localization pattern of germin gene products in salt-stressed and water-grown wheat embryos. Salt stress caused no quantitative changes in the synthesis of germin gene products. However, in situ RNA hybridization revealed changes in the expression site of germin gene products. Coleorhiza cells were found to be the site of germin accumulation in water-grown embryos; however, in saltstressed embryos, germin mRNA accumulated in coleoptile cells instead of coleorhiza tissue.
\end{abstract}

Key words: Germin; In situ hybridization; RT-PCR; Salt stress;

Wheat development 


\section{INTRODUCTION}

Soil salinity is an important agricultural problem, particularly since the majority of crop plants have low salt tolerance. The response of plants to salt stress is a complex phenomenon that involves biochemical and physiological processes as well as morphological and developmental changes (Flowers et al., 1977; Greenway and Munns, 1980). The identification of genes whose expression enables plants to adapt to or tolerate salt stress is essential for breeding programs, but little is known about the genetic mechanisms for salt tolerance. One approach in clarifying the molecular mechanisms involved in salt stress is to identify the genes whose levels change as a result of salt stress. In this aspect, Hurkman et al. (1989) reported that in barley, gene regulation is altered by salt stress and the levels of translatable mRNAs change with salt treatment.

Among the salt stress-responsive gene products, germin and germin-like proteins were identified (Caliskan, 1997; Hurkman et al., 1989). Germin is a homopentameric apoplastic glycoprotein whose synthesis is associated with the onset of growth in germinating wheat embryos (Lane, 1991). Germin genes and proteins were first detected in germinating cereals (Grzelczak et al., 1985), but subsequently, germin-like proteins were also identified in dicotyledonous angiosperms (Michalowski and Bohnert, 1992), gymnosperms (Domon et al., 1995) and mosses (Yamahara et al., 1999). Germins are suggested to be a member of a "superfamily" that comprises various growth-related genes (Dunwell et al., 2000).

Cereal germin proteins have strong oxalate oxidase activity (Lane et al., 1993), an activity that produces one mole of $\mathrm{H}_{2} \mathrm{O}_{2}$ and two moles of $\mathrm{CO}_{2}$ from the degradation of oxalic acid. It is reported that $\mathrm{H}_{2} \mathrm{O}_{2}$ may act as a signaling molecule at low concentration (Luttrell, 1993) or a component of cell wall modifications at high concentrations (Showalter, 1993). Another germin-like protein isolated from the cells of a moss, Barbula unguiculata, was shown to have manganese superoxide dismutase activity (Yamahara et al., 1999). Germin genes and proteins have been shown to be associated with various aspects of plant development (Caliskan, 2000; Lane, 2002) such as the defense system (Berna and Bernier, 1999; Donaldson et al., 2001), embryonic development (Caliskan and Cuming, 2000), photoperiodic oscillations (Ono et al., 1996), and hormonal stimuli (Berna and Bernier, 1997). The accumulation of germin gene products in wheat and barley seedlings in the presence of $\mathrm{NaCl}$ was analyzed previously, but little is known about the possible role of germin gene products during salt stress (Hurkman et al., 1991, 1994; Hurkman and Tanaka, 1996; Berna and Bernier, 1999).

In this paper, reverse transcriptase-polymerase chain reaction (RT-PCR) and in situ RNA hybridization techniques that are especially useful in elucidating the function of a specific gene product were employed for the determination of germin gene products in wheat embryos grown under salt stress. It is also reported here that the localization pattern of germin gene products in salt-treated embryos is different than that grown in water.

\section{MATERIAL AND METHODS}

\section{Plant materials}

Wheat grains (Triticum aestivum L. var. Chinese Spring) were obtained from the John Innes Centre for Plant Science Research, Norwich, UK. Grains were surface-sterilized for 
10 min using a solution of household bleach $\left(1 \%\right.$ free $\left.\mathrm{Cl}_{2}\right)$, washed extensively with sterile water and imbibed at $25^{\circ} \mathrm{C}$ in the dark on two layers of water-soaked filter paper or on 200 $\mathrm{mM} \mathrm{NaCl}$-soaked filter paper for $24 \mathrm{~h}$ after which the embryos were harvested and RNA was extracted as described before (Morris et al., 1990).

\section{Reverse transcriptase-polymerase chain reaction}

RT-PCR was used for the detection of germin gene expression in wheat embryos as described by Wang et al. (1989). A negative control and a positive control were included to show the correct size of amplified product and trueness of signals. Samples were resolved on $6 \%$ acrylamide gels and products were autoradiographically visualized by placing the gel on $\mathrm{X}$-ray film between two glass plates for overnight exposure.

\section{In situ RNA hybridization}

Germin mRNA was detected in embryo sections by in situ hybridization with transcripts of a "germin" cDNA sequence, kindly provided by B.G. Lane (University of Toronto). This sequence was sub-cloned in the plasmid vector pBluescript (Stratagene, La Jolla, CA, USA) for the production of digoxigenin-labeled transcripts with $\mathrm{T}_{7}$ (sense transcripts), and $\mathrm{T}_{3}$ (anti-sense transcripts) RNA polymerases. Probes were subjected to mild alkaline hydrolysis by incubation

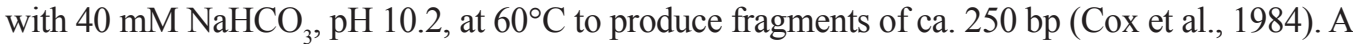
modified procedure of Caliskan and Cuming (1998) was employed for localization of mRNA in situ. Tissue was prepared for sectioning by fixation in $4 \%(\mathrm{w} / \mathrm{v})$ paraformaldehyde in PBS at $4{ }^{\circ} \mathrm{C}$, dehydrated through an ethanol series on ice, and embedded in paraffin wax using Histolene ${ }^{\mathrm{TM}}$ (CellPath, Hemel Hempsted, UK) as the infiltrating solvent. Sections $(10 \mu \mathrm{m})$ were mounted on poly-L-lysine (Sigma, UK)-coated slides at $42^{\circ} \mathrm{C}$ overnight, deparaffinized and rehydrated through an ethanol series for hybridization with strand-specific probes. The sections were incubated with pronase $(0.125 \mathrm{mg} / \mathrm{mL}$ in $50 \mathrm{mM}$ Tris-Cl, $5 \mathrm{mM}$ EDTA, $\mathrm{pH} 7.5)$, and post-fixed with $4 \%(\mathrm{w} / \mathrm{v})$ paraformaldehyde in PBS. Sections were acetylated with acetic anhydride $(0.5 \%(\mathrm{v} / \mathrm{v})$ in triethanolamine- $\mathrm{HCl}, \mathrm{pH}$ 8) prior to prehybridization at room temperature with $0.3 \mathrm{M} \mathrm{NaCl}$, $10 \mathrm{mM}$ sodium phosphate buffer, $10 \mathrm{mM}$ Tris-Cl, $5 \mathrm{mM}$ EDTA - 50\% (v/v) formamide, $10 \%$ (w/v) dextran sulfate, $0.1 \%(\mathrm{w} / \mathrm{v})$ tRNA, 1X Denhardts solution, $\mathrm{pH} 6.8$, for $30 \mathrm{~min}$. Sections were then incubated with buffer containing the DIG-labeled probe at a final concentration of 3 $\mu \mathrm{g} / \mathrm{mL}$ and incubated overnight at $50^{\circ} \mathrm{C}$. Sections were washed in $2 \mathrm{X} \mathrm{SSC}, 50 \%(\mathrm{v} / \mathrm{v})$ formamide at $50^{\circ} \mathrm{C}$, then incubated with $20 \mu \mathrm{g} / \mathrm{mL}$ Rnase A in $0.5 \mathrm{M} \mathrm{NaCl}, 10 \mathrm{mM}$ Tris-Cl, $\mathrm{pH} 7.7,1 \mathrm{mM}$ $\mathrm{Na}_{2}$ EDTA at $37^{\circ} \mathrm{C}$ for $30 \mathrm{~min}$. After a final wash in PBS, hybridized probe was detected using antidigoxigenin antiserum at a 1:3000 dilution, according to manufacturer instructions. Sections were examined by light microscopy and photographed with Kodak Ektachrome Elite II color film.

\section{RESULTS}

\section{Quantitative determination of germin gene products by RT-PCR}

Once the germin genes were shown to be responsive to biotic and abiotic factors, it was intriguing to determine quantitative changes (by RT-PCR) and spatial localizations (by in 
situ RNA hybridization) of germin gene products. The quantitative changes of germin mRNA was analyzed using RT-PCR, which has been previously shown to be very useful in detecting quantitative changes in target RNA concentrations (Ewing and Bennett, 1994). In this application, a positive control and a negative control were included to indicate the correct size of amplified product and to avoid contamination, respectively.

In this paper, RT-PCR was successfully used to detect germin mRNAs in germinating wheat embryos. As seen in Figure 1, levels of germin mRNAs appear to remain unchanged in water-grown (control) embryos (Figure 1, lane 1) and in salt-stressed embryos (Figure 1, lane 2 ). The control experiments gave the correct signals as expected (Figure 1, lanes 3 and 4). The results obtained are in accordance with those reported by Berna and Bernier (1999) who also found no change in germin synthesis upon salt stress. In contrast to our results, it has been shown that salt stress causes a change in the accumulation of germin in various plants (Hurkman et al., 1991, 1994; Nakata et al., 2002).

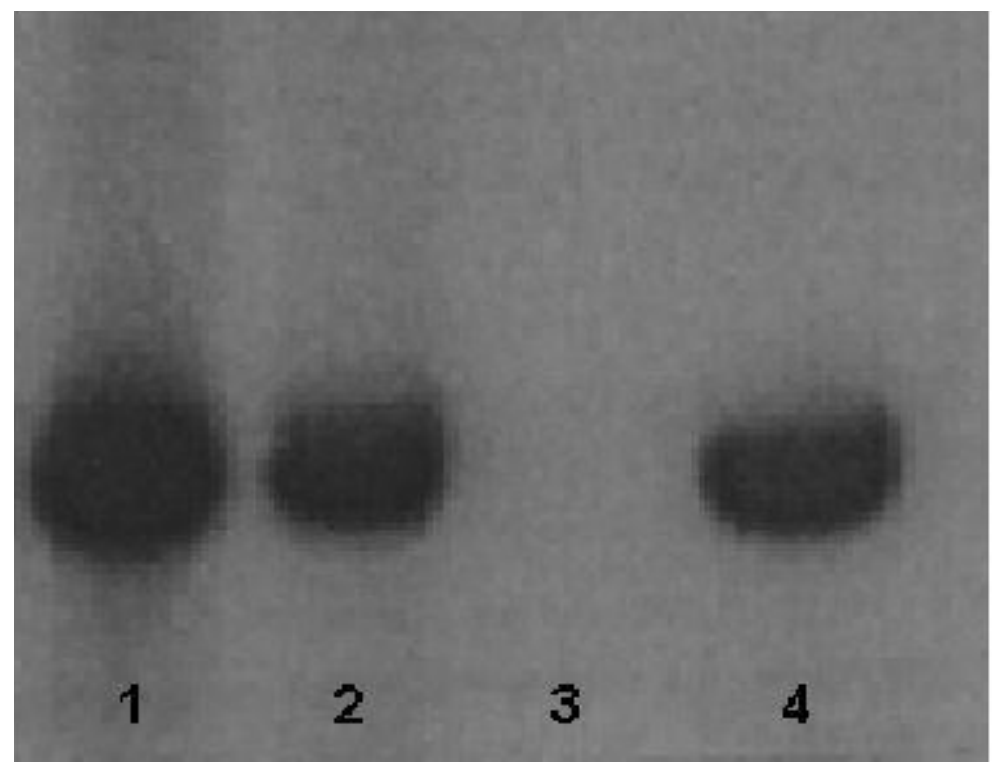

Figure 1. Determination of germin gene expression by RT-PCR in water-grown wheat embryos (lane 1) and saltstressed embryos (lane 2). A negative control (lane 3) and positive control (lane 4) were used to show the trueness of the signals.

\section{Localization pattern of germin gene products}

Once germin mRNA was determined to be equally synthesized in salt-stressed embryos and water-grown embryos (Figure 1), it was interesting to establish whether germin mRNA expression follows the same localization pattern or not. Analysis of localization pattern of germin mRNA in salt-stressed embryos and in water-grown embryos, by in situ RNA hybridization (Figure 2), revealed a shift in the localization pattern of germin 
gene products upon salt stress treatment. Although germin mRNA expression was associated with the cells of the coleorhiza, which is a protective tissue surrounding primary and secondary roots in water-grown embryos (Figure 2A), in salt-stressed embryos, germin mRNA was synthesized irregularly in the cells of the coleoptiles, which is another protective tissue of early wheat embryo development (Figure 2B). The embryo sections reacted with DIG-labeled sense probe (Figure 2C) gave no signal of germin mRNA expression, which is an indication of trueness of signals obtained in Figure 2A,B.
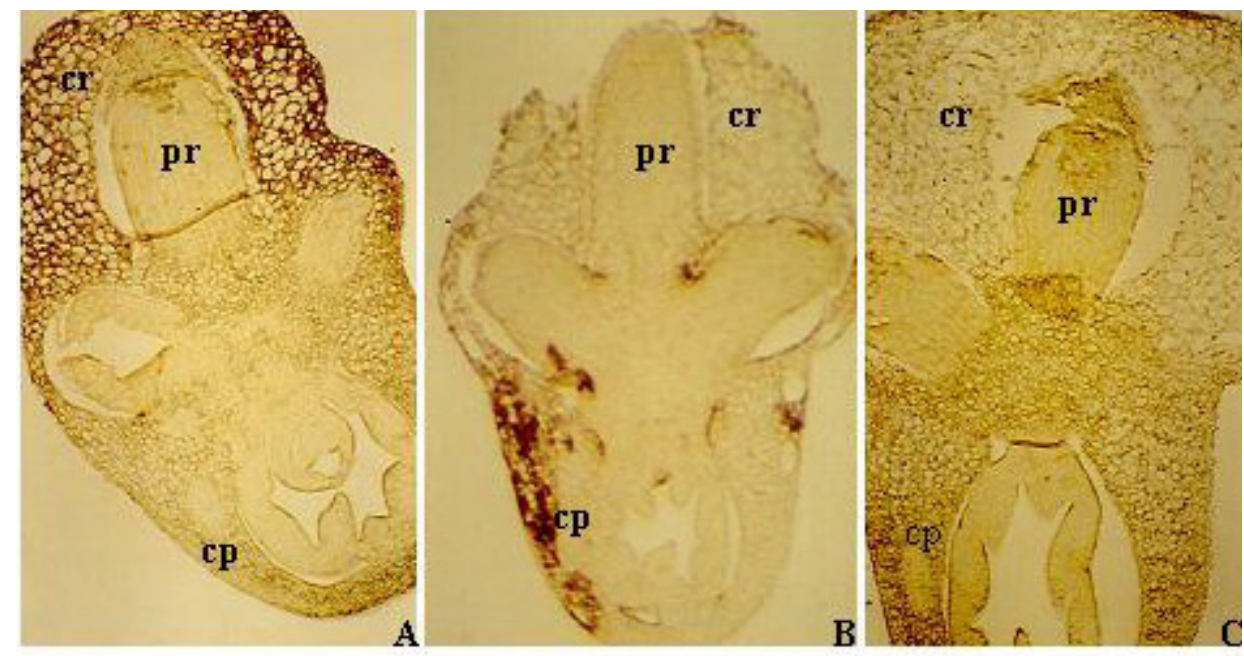

Figure 2. Localization of germin gene expression by in situ RNA hybridization in water-grown embryos (A) and in salt-stressed embryos (B). The control section was reacted with sense probe (C). $\mathrm{pr}=$ primary root, $\mathrm{cr}=$ coleorhiza, $\mathrm{cp}=$ coleoptile.

\section{DISCUSSION}

Germin was first identified as a specific marker for wheat, and more generally cereal, germination (Lane, 1991). Since its identification, it has become obvious that germins and germin-like proteins are ubiquitous in the plant kingdom (Bernier et al., 1987; Lane et al., 1991; Caliskan, 2000). However, it has also become obvious that most of the germin-like proteins are not germination-specific proteins. They can be found in most developmental stages and also in response to a wide range of biotic and abiotic factors, including $\mathrm{NaCl}$ (Domon et al., 1995; Dumas et al., 1995; Dunwell, 1998; Caliskan, 2000).

Germin and germin-like proteins are suggested to be salt-responsive gene products and their response to salt stress seems to be varied. For example, the accumulation of germin mRNA is upregulated during the growth of germinating barley seedlings in the presence of $\mathrm{NaCl}$ (Hurkman and Tanaka, 1996). In contrast, it is reported that in the ice plant (Mesembryanthemum crystallinum) the synthesis of germin-like proteins declined after salt stress (Michalowski and Bohnert, 1992). On the other hand, Berna and Bernier (1999) and the present study indicated that in wheat seedlings germin synthesis remained unchanged in the presence of $\mathrm{NaCl}$. More studies are needed to explain this contradiction. 
In situ RNA hybridization is one of the most powerful techniques developed for localizing the expression site of particular gene products at the cell, tissue and organ levels. This method is particularly useful in understanding the function of specific gene products in particular tissues and the relation between tissue function and its localization in the whole structure of an organ (Ranjhan et al., 1992). Previously, it was shown that germin mRNA is synthesized in the cells of the coleorhiza in wheat seedlings, and it was considered that the enzymatic activity of germin, oxalate oxidase, could play an important role in metabolic regulation, particularly in cell wall modification during germination and seedling development (Caliskan and Cuming, 1998). It is well known that stress factors alter the synthesis of gene expression. Indeed, upon salt stress, the localization pattern of germin gene expression was changed, as seen in the present study.

In this paper, it is shown that although the water-grown embryos and salt-stressed embryos accumulate similar amounts of germin mRNA, the synthesis site of germin mRNA is completely different. In germinating wheat embryos salt stress somehow caused germin mRNA to be synthesized in coleoptile instead of coleorhiza cells. An explanation for this shift will help us to have a better understanding of stress physiology in plants.

\section{CONCLUSION}

This paper showed that under salt stress conditions germin expression remained unchanged in developing wheat seedlings as previously claimed by Berna and Bernier (1999). It was also shown that although overall germin expression is not altered, the site of germin expression is shifted from coleorhiza to coleoptile. The results clearly indicate that salinity unexpectedly affects tissue specificity of germin expression other than overall expression levels of germin. In the future, our studies will focus on elucidating the mechanisms by which salt stress alters the site of germin expression and the role of germin in coping with salt stress.

\section{ACKNOWLEDGMENTS}

Research supported by Tubitak in Turkey.

\section{REFERENCES}

Berna A and Bernier F (1997). Regulated expression of a wheat germin gene in tobacco: oxalate oxidase activity and apoplastic localization of the heterologous protein. Plant Mol. Biol. 33: 417-429.

Berna A and Bernier F (1999). Regulation by biotic and abiotic stress of a wheat germin gene encoding oxalate oxidase, a $\mathrm{H}_{2} \mathrm{O}_{2}$-producing enzyme. Plant Mol. Biol. 39: 539-549.

Bernier F, Lemieux G and Pallotta D (1987). Gene families encode the major encystment-specific proteins of Physarum polycephalum plasmodia. Gene 59: 265-277.

Caliskan M (1997). Temporal and Spatial Analysis of Germin Synthesis. PhD thesis, University of Leeds, Leeds.

Caliskan M (2000). Germin, an oxalate oxidase, has a function in many aspects of plant life. Turk. J. Bot. 24: 714-724.

Caliskan M and Cuming AC (1998). Spatial specificity of $\mathrm{H}_{2} \mathrm{O}_{2}$-generating oxalate oxidase gene expression during wheat embryo germination. Plant J. 15: 165-171.

Caliskan M and Cuming AC (2000). Germin-like oxalate oxidase activity increase in auxin-treated wheat coleoptiles. Turk. J. Bot. 24: 329-335.

Cox KH, DeLeon DV, Angerer LM and Angerer RC (1984). Detection of mRNAs in sea urchin embryos by in situ hybridization using asymmetric RNA probes. Dev. Biol. 101: 485-502.

Domon JM, Dumas B, Laine E, Meyer Y, et al. (1995). Three glycosylated polypeptides secreted by several embryogenic 
cell cultures of pine show highly specific serological affinity to antibodies directed against the wheat germin apoprotein monomer. Plant Physiol. 108: 141-148.

Donaldson PA, Anderson T, Lane BG, Davidson AL, et al. (2001). Soybean plants expressing an active oligomeric oxalate oxidase from the wheat gf-2.8 (germin) gene are resistant to the oxalate-secreting pathogen Sclerotina sclerotiorum. Physiol. Mol. Plant Pathol. 59: 297-307.

Dumas B, Freyssinet G and Pallett KE (1995). Tissue-specific expression of germin-like oxalate oxidase during development and fungal infection of barley seedlings. Plant Physiol. 107: 1091-1096.

Dunwell JM (1998). Cupins: a new superfamily of functionally diverse proteins that include germins and plant storage proteins. Biotechnol. Genet. Eng. Rev. 15: 1-32.

Dunwell JM, Khuri S and Gane PJ (2000). Microbial relatives of the seed storage proteins of higher plants: conservation of structure and diversification of function during evolution of the cupin superfamily. Microbiol. Mol. Biol. Rev. 64: 153-179.

Ewing NN and Bennett AB (1994). Assessment of the number and expression of P-type H(+)-ATPase genes in tomato. Plant Physiol. 106: 547-557.

Flowers TJ, Troke PF and Yeo AR (1977). The mechanism of salt tolerance in halophytes. Annu. Rev. Plant Physiol. 28: 89-121.

Greenway H and Munns R (1980). Mechanisms of salt tolerance in nonhalophytes. Annu. Rev. Plant Physiol. 31: 149-190.

Grzelczak ZF, Rahman S, Kennedy TD and Lane BG (1985). Germin. Compartmentation of the protein, its translatable mRNA, and its biosynthesis among roots, stems, and leaves of wheat seedlings. Can. J. Biochem. Cell Biol. 63: 1003-1013.

Hurkman WJ and Tanaka CK (1996). Effect of salt stress on germin gene expression in barley roots. Plant Physiol. 110: 971-977.

Hurkman WJ, Fornari CS and Tanaka CK (1989). A comparison of the effect of salt on polypeptides and translatable mRNAs in roots of a salt-tolerant and a salt-sensitive cultivar of barley. Plant Physiol. 90: 1444-1456.

Hurkman WJ, Tao HP and Tanaka CK (1991). Germin-like polypeptides increase in barley roots during salt stress. Plant Physiol. 97: 366-374.

Hurkman WJ, Lane BG and Tanaka CK (1994). Nucleotide sequence of a transcript encoding a germin-like protein that is present in salt-stressed barley (Hordeum vulgare L.) roots. Plant Physiol. 104: 803-804.

Lane BG (1991). Cellular desiccation and hydration: developmentally regulated proteins, and the maturation and germination of seed embryos. FASEB J. 5: 2893-2901.

Lane BG (2002). Oxalate, germins, and higher-plant pathogens. IUBMB Life 53: 67-75.

Lane BG, Bernier F, Dratewka-Kos E, Shafai R, et al. (1991). Homologies between members of the germin gene family in hexaploid wheat and similarities between these wheat germins and certain Physarum spherulins. J. Biol. Chem. 266: 10461-10469.

Lane BG, Dunwell JM, Ray JA, Schmitt MR, et al. (1993). Germin, a protein marker of early plant development, is an oxalate oxidase. J. Biol. Chem. 268: 12239-12242.

Luttrell BM (1993). The biological relevance of the binding of calcium ions by inositol phosphates. J. Biol. Chem. 268: 1521-1524.

Michalowski CB and Bohnert HJ (1992). Nucleotide sequence of a root-specific transcript encoding a germin-like protein from the halophyte Mesembryanthemum crystallinum. Plant Physiol. 100: 537-538.

Morris PC, Kumar A, Bowles DJ and Cuming AC (1990). Osmotic stress and abscisic acid induce expression of the wheat Em genes. Eur. J. Biochem. 190: 625-630.

Nakata M, Shiono T, Watanabe Y and Satoh T (2002). Salt stress-induced dissociation from cells of a germin-like protein with Mn-SOD activity and an increase in its mRNA in a moss, Barbula unguiculata. Plant Cell Physiol. 43: 1568-1574.

Ono M, Sage-Ono K, Inoue M, Kamada H, et al. (1996). Transient increase in the level of mRNA for a germin-like protein in leaves of the short-day plant Pharbitis nil during the photoperiodic induction of flowering. Plant Cell Physiol. 37: 855-861.

Ranjhan S, Karrer EE and Rodriguez RL (1992). Localizing $\alpha$-amylase gene expression in germinated rice grains. Plant Cell Phisiol. 33: 73-79.

Showalter AM (1993). Structure and function of plant cell wall proteins. Plant Cell 5: 9-23.

Wang AM, Doyle MV and Mark DF (1989). Quantitation of mRNA by the polymerase chain reaction. Proc. Natl. Acad. Sci. U. S. A. 86: 9717-9721.

Yamahara T, Shiono T, Suzuki T, Tanaka K, et al. (1999). Isolation of a germin-like protein with manganese superoxide dismutase activity from cells of a moss, Barbula unguiculata. J. Biol. Chem. 274: 33274-33278. 